\title{
Tax Avoidance and Corporate Risk: Evidence from a Market Facing Economic Sanction Country
}

\author{
Mahdi SALEHI $^{1}$, Sharbanoo KHAZAEI ${ }^{2}$, Hossein TARIGHI ${ }^{3}$ \\ Received: July 14, 2019 Revised: September 16, 2019 Accepted: September 24, 2019
}

\begin{abstract}
The current study aims to investigate the relationship between tax avoidance and firm risk in an emerging market called Iran. The study population consists of 400 observations and 80 companies listed on the Tehran Stock Exchange (TSE) over a five-year period during 2012 and 2016. The statistical model used in this study is a multivariate regression model; besides, the statistical technique used to test the hypotheses proposed in this research is panel data. The results showed that low effective tax rate (tax avoidance) is more consistent than the higher effective tax rate. Moreover, there is no significant relationship between tax avoidance and future tax rate volatility. The findings also proved that lower effective tax rates are positively associated with future stock price volatility. This implies that since Iranian firms have many financial problems because of economic sanctions, they have a tendency to delay the disclosure of bad news about their firms. Needless to say, when a huge number of negative news reaches its peak, they immediately will enter the market and lead to a remarkable fluctuation in stock prices.
\end{abstract}

Keywords : Tax Avoidance, Tax Rate Volatility, Stock Price Volatility, Firm Risk, Iran

JEL Classification Code : D21, G01, G32

\section{Introduction}

Following the specialization of the activities of companies as well as separation of management from ownership, managers as shareholder's agents manage the company' operations. By establishing an agency relationship in this way, each side of the relationship seeks to maximize its benefits. Since the utility function of the parties involved in the agency relationship is different, there is a conflict of interest between them (Salehi, Tarighi, \& Safdari, 2018). Therefore, it is possible that one of the parties, in line with his or her own interests, will take actions that contradict the

1 First Author and Corresponding Author, Associate Professor, Economics and Administrative Sciences, Ferdowsi University of Mashhad, Iran. [Postal Address: Vakilabad, Mashhad, Khorasan Razavi, 9177948974, Iran] Email: Mehdi.salehi@um.ac.ir

2 Economics and Administrative Sciences, Gaenat Branch, Islamic Azad University, Iran. Email: shahrbanookhazaei@gmail.com

3. Economics and Administrative Sciences, Attar Institute of Higher Education, Mashhad, Iran. Email: hossein.tarighi@outlook.com

(c) Copyright: Korean Distribution Science Association (KODISA)

This is an Open Access article distributed under the terms of the Creative Commons Attribution Non-Commercial License (http://Creativecommons.org/licenses/by-nc/4.0/) which permits unrestricted noncommercial use, distribution, and reproduction in any medium, provided the original work is properly cited. goals of other groups. One of the most significant conflicts in agency relations is the conflict between managers and shareholders of the company. There is a wide range of incentives such as rewards contracts and management' tenure that encourage executives to refrain from disclosing negative information and accumulate them within the company (Kothari, Shu, \& Wysocki, 2009). Apparently, if managers take action to maintain bad news inside the company for a long period of time, there is a big gap (stock price bubble) between the intrinsic price of the company's stock and the value determined by investors. When the mass of accumulated negative news reaches the point of the explosion, suddenly bad news enters the market and leads to the loss of price bubbles and falling stock prices (Hutton, Marcus, \& Tehranian, 2009; Moradi, Bagherpour Velashani, \& Rostami, 2016).

One of the other conflicts in the company's stakeholders is the conflict of interests that exists between the state and the shareholders. In the broad approaches of the corporate governance system, the government also plays a role as one of the main stakeholders in the company. In such a way that if the operation of the company leads to profit, before making any decision regarding this benefit, the 
government's share of it should be calculated and paid under the title of tax. It is clear that Tax represents an important cost and a decrease in the remaining cash for the company and its shareholders. It is argued that taxes are like other costs, so firm directors have the right to minimize taxes in legal ways. Hence, this motive naturally exists that the firm and its shareholders through their directors try to avoid paying taxes (Hanlon \& Heitzman, 2010). Therefore, it can be said that in a situation where the company is attempting to engage in tax evasion so as to reduce costs, the possibility of accumulating the negative information within the company and the risk of falling the stock prices will increase.

Although tax avoidance or tax minimization leads to an increase in the remaining funds for corporate shareholders, managers sometimes do not use the tax avoidance activities to increase the value of the company, and they take their opportunistic behavior in order not to disclose this news inside the company (Desai \& Dharmapala, 2009). In this regards, Hanlon and Heitzman (2010) argued that companies that use tax havens do not respect social responsibility, and the market shows a negative reaction to these companies whereby the value of the company is reduced. It should be not the ed that may show a negative the reaction to tax avoidance activity. In other words, Investors may interpret this news as the inefficiency of management. In fact, shareholders may believe that such opportunistic behaviors will have negative consequences such as the loss of reputation and costly investigations by tax authorities with the possibility of heavy fines which will reduce stock prices and increase stock risk (Graham, 2014).

With respect to Iran market, it can be suggested that the majority of Iranian firms experienced many considerable financial problems since Iran faced severe economic sanctions during the time period under study (Salehi et al., 2018). In this dire economic situation, there are several fundamental questions that the main goal of this research is to find their answers. Firstly, we are going to know if in an inflationary economy with rising prices, companies were likely to have to find ways of tax evasion in order to reduce part of their costs. Secondly, do low tax rates tend to be more persistent than high tax rates? In addition, do measures of tax avoidance have an influential impact on future tax rate volatility or future overall firm risk?

The rest of our research is organized as follows: next section frames the study into a theoretical framework, hypotheses development, and literature. Part three describes the research design and outlines where data is obtained and the sample selection procedure. Section four then presents the main results and implications drawn from statistical analyses and. eventually, the last district presents the concluding remarks.

\section{Theoretical Framework and Literature Review}

Tax avoidance is defined as the legal use of the tax system for personal interests, and also is to reduce the amount of tax payable by the means provided by the law itself (Pasternak \& Rico, 2008). It is noticeable that tax avoidance does not relate to the illegal activities that reduce government revenues, which is needed for infrastructure and general welfare services. Based on the existing literature, there are two perspectives on the relationship between tax avoidance and company value. The first view is regarding value enhancing. Based on this view, capital market activists appreciate the importance of tax avoidance activities, and they see it as a worthwhile activity. Desai and Dharmapala (2009) are of the opinion that as tax avoidance reduces the transfer of wealth from shareholders to the state, therefore it is a valuable activity. In this regards, as tax cost reduces corporate profit, many firms largely use tax avoidance activities with the aim of reducing their taxable income (Noor, Fadzillah, \& Mastuki, 2010). As a result, tax avoidance is becoming a major concern for governments.

The second view is from the perspective of agency theory that the non-transparent and complex nature of tax avoidance activities allows management to hide bad news in pursuit of its opportunistic goals (Chen \& Chu, 2005; Crocker \& Slemrod, 2005; Armstrong, Blouin, \& Larker, 2012). According to agency theory, corporate managers often act based on their personal interests, and the shareholders' interests will not be the main concern (Salehi et al., 2017). Hence, it is predicted that the firms engage in tax evasion are not keen on maximizing the shareholder's wealth (Desai \& Dharmapala, 2009). Separation of ownership from management can lead to taking tax decisions in the firm which reflects the personal interests of the manager. Hence, the challenge facing shareholders and the board is to find a mix of control and incentive mechanisms to minimize agency costs. (Jensen \& Meckling, 1976). In spite of the fact that the tax avoidance may also decrease the financial leverage (Graham \& Tucker, 2006; Richardson, Taylor, \& Lanis, 2016), there are several important studies that have shown that tax avoidance increases firm risk strikingly. For instance, Rego and Wilson (2012) examined equity risk incentives as one determinant of corporate tax aggressiveness. Their results showed that larger equity risk incentives are positively associated with greater tax risk. Crabtree and Maher (2009) also found that firms with high tax avoidance (the first $5 \%$ of firms with effective tax rates) demonstrate low credit in their debts. Based on the analysis of the sample of large American banks that take a bank loan, Hasan, Hoi, Wu, and Zhang (2014) showed that firms largely avoid taxing are considered by lenders as more risky firms that have higher interest rates; so tax evasion further means higher debt costs.

Clearly, there are several reasons why tax avoidance can exacerbate corporate risk. The first reason is that tax avoidance persuades tax authorities not to trust the firm's future tax payments. The second one is that the magnitude of tax avoidance often is considered as a prominent indicator of the risk of the firm's investments. Furthermore, since effective strategies for tax evasion require the use of a 
complex and ambiguous reporting system, it will result in increasing the uncertainty with regard to the firm's future cash flows and plunging the information transparency (Guenther, Matsunaga, \& Williams, 2016).

If we look at the prior studies, quite a bit of robust evidence showed that corporate managers prefer low effective tax rate (avoiding taxes) more than higher ones; however, one should not forget that investments in tax reduction rise the riskiness of the firm. For example, Shevlin, Urcan, and Vasvari (2013) carried out a research entitled "Corporate tax avoidance and public debt costs" in America. Using a large sample of US corporate bonds, they realized that corporate tax avoidance is positively linked to the cost of public debt particularly when equity holders and the management have the motive to expropriate bondholders' wealth and when the probability of an IRS audit is high. Badertscher, Katz, and Rego (2013) also concluded that corporate tax avoidance is increasing because of the separation of ownership and control. In another research, Chen, Ge, Louis, and Zolotoy (2019) indicated that the firms have higher stock liquidity participate less in extreme tax avoidance because the shareholders' monitoring of corporate management increases sharply. Dyreng, Hanlon, and Maydew (2018) witnessed a positive association between tax avoidance and tax uncertainty. They also suggested that this relation is sturdier for companies with regular patent filings and tax haven subsidiaries. It seems that what has already been said in the research literature is consistent with the view that the more dangerous the firm's tax positions, the bigger the likelihood that the firm will be enforced to repay the taxes. Sunder (2015), and Guenther et al. (2016) argued that when tax evasion surges the possibility of paying a high tax rate in the future by the firm, low tax rates are expected to reveal a lower grade of persistence than great tax rates.

The question now is whether such an expectation could be speculated from the Iranian market with its unique features. In order to find this answer, two very important points regarding the Iranian market should be considered. The first point about Iran market is that the quality of corporate governance system is relatively weak. For example, Mashaykhi and Seyyedi (2015) conducted a study entitled "Corporate Governance and Tax Avoidance" in Iran context. Their findings displayed that there is no significant connection between some of the corporate governance mechanisms such as institutional ownership, board independence, and board size with tax avoidance. In addition, Salehi et al. (2018) found that the board independence and managers who invest in companies under their own management do not have any impact on the amount of audit fee in Iran market. Generally speaking, the evidence have shown that $C G$ mechanisms do not have outstanding ability to reduce agency problems and information asymmetry. Therefore, it is not reasonable to expect regulatory mechanisms in Iran to prevent tax evasion. The second point is that as previously mentioned, there have been unprecedented economic sanctions against Iran country and many Iranian firms are in financial strain (Salehi et al., 2018). So, Iranian firms had many financial problems between 2012 and 2016, and they were likely to engage in tax escaping to mask their weak financial performance. To put it another way, in such unfortunate financial circumstances, financial managers are expected to be more risk-averse for tax avoidance' actions in order to increase the firm value. Hence, the low effective tax rate is anticipated to be more consistent than the higher effective tax rate.

H1: Low effective tax rate is more consistent than the higher effective tax rate.

As for the firm's future tax rates, it can be interpreted that uncertainty about the firm's future tax rates may are influenced by ambitious strategies of tax avoidance. Guenther et al. (2016) supposed that since the greater dependence on grey area tax avoidance or short-term tax motivations results in the uncertainty growth about the firm's future tax payments, low tax rates are set to have a larger proportion of uncertainty. In general, the second hypothesis of the research is as follows:

H2: Low effective tax rate has a positive correlation with future tax rate volatility.

Based on widespread definitions of the corporate governance system, the government is one of the main stakeholders in the company that receives its share as a tax on corporate profits (Kim, Li, \& Zhang, 2011). In Iran, according to Article 105 of the Direct Taxation Act of 2001, 25 percent of the profits of legal persons after deduction of legal exemptions belong to the government and should be paid to the state as taxes. What is worth mentioning is that tax is one of the items that is deducted from the profits of the companies in order to obtain dividend profits among the shareholders. Therefore, according to the laws and regulations, the payment of the state's share of the corporate profits is superior to the division of profits among shareholders. In other words, the government regards itself at a position even higher than the main shareholders of the company. Given that tax payments lead to a reduction in the value of the company and the share of the shareholders, it is natural for them to adopt strategies to reduce tax payments, one of which is tax evasion (Kim et al., 2011; Foroghi, Mirzaei, \& Rasaiian, 2012). Desai and Dharmapala (2009) think that tax evasion requires the use of a complex and obscure reporting structure so that tax authorities cannot discover it. Bushman and Smith (2001), Kim et al. (2011), and also Guenther et al. (2016) concluded that the ambiguity resulting from tax evasion activities can exacerbate agency conflicts between managers and shareholders, and the negative impact of tax evasion on the company's information environment allows managers to deviate from policies aimed at maximizing the stockholders' wealth for a long time. Therefore, it can be said that in the event that the company engages in tax escaping, due to the ambiguity and 
complexity of the information environment and the financial reporting structure of the company, managers have more opportunities and abilities to maintain and accumulate negative information within the company. In such a situation, the risk of falling stock prices will increase.

One of the negative phenomena that typically occurs in securities markets is the lack of information symmetry that leads to inappropriate economic decisions by investors. The findings of Balakrishnan, Blouin, and Guay (2018) showed that when aggressive tax planning increase, corporate information transparency decreases significantly. Apparently, tax evasion has a negative impact on the reporting environment (Chen, Chen, Cheng, \& Shevlin, 2010; Guenther et al., 2016). Regarding the separation of ownership from management, managers are always trying to provide a good image of the business unit, and also tend to delay the disclosure of bad news. The accumulation of negative news by managers in this way creates a stock price bubble. When a huge number of negative news reaches its peak, they immediately will enter the market and lead to a remarkable fall in stock prices (Hutton et al., 2009; Foroghi et al., 2012; Moradi et al., 2016; Guenther et al., 2016). The results of several studies conducted in Iran market are moderately similar. Based on a sample selected among the firms listed on TSE from 2001 to 2009, Foroghi et al. (2012) saw a positive and significant relationship between tax evasion and future stock price crash risk. In another study, Moradi et al. (2016) surveyed the effect of tax evasion on future stock price crash risk in Iran market. They found that tax evasion is positively associated with future stock price crash risk. Taking together, since Iran market struggled with economic sanction during 2012 to 2016, and most firms had massive financial problems, it is reasonably predicted that Iranian managers were likely to hide bad news about their firms so as to keep their main shareholders. Subsequently, the last hypothesis of our paper is as follows:

H3: Effective Tax Rate (ETR) has a positive correlation with future stock price volatility.

\section{Research Methodology}

The present research is applied in terms of purpose. From the perspective of the nature and method of the research is a descriptive-correlation type. Because it examines the existing situation on the one hand, and it determines the relationship between different variables using regression analysis on the other hand. According to econometric science, in this study, the F-Limer test initially is used for the sake of identifying whether the model is fitted to the Ordinary Least Squares (OLS) or panel data. Following this, the Hausman test is used to determine whether a panel data with fixed effects should be used or a panel data with random effects. The statistical population of this study is all companies listed on the Tehran Stock
Exchange, over a five-year period between 2012 and 2016. The sample was determined by systematic deletion. So companies that have the following features were included in the sample.

1. Firms must not change their fiscal year during the periods

2. According to the research' time period (2012-2016), the company is listed on the TSE before the year 2012 and its name is not removed from the listed companies by the end of 2016.

3. Financial information required for this research during the study period, i.e. from 2012 to 2016 , must be presented completely.

4. The type of the business activity should be manufacturing and thus investment companies, leasing, credit, and financial institutions and banks are not included in our sample due to these companies have quite different natures in terms of reporting and ownership structure (Salehi et al., 2018).

Taking account of the above conditions, a sample size of 80 companies from firms listed on TSE has been selected.

\subsection{Research Models}

The purpose of the first hypothesis is knowing if the low effective tax rate is more consistent than the higher effective tax rate in the Iran context. To examine the first hypothesis, the effective tax rate of companies has been used for five consecutive years, and we examine its continuity by comparing different consecutive years. Initially, for this purpose, the following steps are taken respectively.

1. Calculating the effective tax rate for each year of the company;

2. Calculating the average effective tax rate for the entire years of the company;

3. Calculating difference of the effective tax rate of each year from the total average calculated in step (2);

4. If the difference calculated in step (3) is a negative number, it will be equal to zero, and otherwise, it will be one;

5. Calculating the mean of zero and one numbers obtained from step (4);

6. Finally, if the average number calculated in step (5) is close to 0 , it indicates higher sustainability of low effective tax rates, and if it is close to 1 suggesting higher sustainability of higher effective tax rates.

As regards the second hypothesis of this paper, our purpose is investigating the association between a low effective tax rate (tax avoidance) and future tax rate volatility. Thus, following Guenther et al. (2016), we used the below model in this study.

Cash-ETR-Volatility $=\alpha_{0}+\alpha_{1}$ TAX $_{\text {it }}+\alpha_{2}$ size $_{\text {it }}+\alpha_{3}$ BTM $+\alpha_{4}$ Leverage $_{\text {it }}+\alpha_{5}$ Abn-Accruals At $+\alpha_{6}$ Vol-PTBI $_{\text {it }}+\alpha_{7}$ INST_OWN $_{i t}+\alpha_{8}$ Vol-cashflow $_{\text {it }}+\alpha_{9}$ NOLCF $_{i t}+\alpha_{10}$ CHG$\mathrm{NOLCF}_{\text {it }}+\alpha_{11}$ LOSS $_{\text {it }}+\alpha_{12}$ SHARES_OUT $_{\text {it }}+£_{\text {it }}$. 
Where,

Cash ETR Volatility: the effective tax rate of firm $i$ in year $t$, which is equal to the annual standard deviation of cash tax, divided by income during the five years period.

TAX: a proxy for tax avoidance. Model of discretionary book-tax differences developed by Frank, Lynch, and Rego (2009). DTAX equals the residual from the following regression estimated by year and two-digit SIC code: PermDiff it $=\mathrm{a} 0+\mathrm{a} 1(1 /$ ATit -1$)+\mathrm{a} 2$ INTANG it + a3 UNCON it + a4 MI it + a5 CSTE it + a6 DNOL it + a7 LAGPERM it $+£_{\text {it. }}$

Size: the size of firm $i$ in year $t$ is the natural logarithm of total assets (TA);

BTM: year-end book value of equity over the price per share times the total number of shares outstanding;

Leverage: leverage of firm $i$ in year $t$., which sum of noncurrent debt divided by the sum of assets at the beginning of the year;

Abn-Accruals: a square of year-end discretionary accruals, expected using the modified Jones model from Dechow, Sloan, and Sweeney (1996);

Vol-PTBI: standard deviation of annual pretax income (PI) scaled by lagged total assets (AT) measured over a five-year period;

Inst_Own: firm's average institutional ownership measured over the fiscal year;

Vol-cash flow: risk of the cash flow of firm $i$ in year $t$, (operating profit - tax + depreciation cost - net investment - changes in working capital) / total assets;

NOLCF: net operating loss carryforward (NOLCF) scaled by lagged total assets (AT);

CHG_NOLCF: change in net operating loss carryforward (NOLCF) scaled by lagged total assets (AT);

Loss: an indicator variable equal to one if a firm has negative pretax income;

Shares_Out: log of the firm's common shares outstanding.

As for the third hypothesis of the research, we want to know if there is a significant relationship between the Effective Tax Rate (ETR) and future stock price volatility. To achieve this goal, similar to Guenther et al. (2016), the following research model has been used in this study.

SD_RET $=\alpha_{0}+\alpha_{1} \mathrm{TAX}_{\mathrm{it}}+\alpha_{2}$ size $_{\mathrm{it}}+\alpha_{3} \mathrm{BTM}+\alpha_{4}$ Leverage $_{\mathrm{it}}$ $+\alpha_{5}$ Abn-Accruals ${ }_{i t}+\alpha_{6}$ Vol-PTBI $_{\text {it }}+\alpha_{7}$ INST_OWN $_{\text {it }}+\alpha_{8}$ Vol-cashflow $_{\text {it }}+\alpha_{9}$ NOLCF $_{\text {it }}+\alpha_{10}$ CHG-NOLCF $_{\text {it }}+\alpha_{11}$ LOSS $_{\text {it }}+\alpha_{12}$ SHARES_OUT $i t+\mathfrak{f}_{\text {it }}$.

Where, SD-RET: future risk of firm $i$ in year $t$, which is the standard deviation of monthly returns of stock in the future year.

\section{Results}

\subsection{Descriptive Statistics}

In order to better understand the research population and to become more familiar with the research variables, at first it is necessary to describe these the statistical data before analyzing them. The statistical description of the data is a step towards identifying the governing pattern and the basis for explaining the relationships between the variables used in the research. Descriptive statistics of the research variables including Mean, Standard Deviation, Minimum, and Maximum are presented in Table 1:

Table 1: Descriptive statistics of the research variables

\begin{tabular}{|c|c|c|c|c|}
\hline Variables & Min. & Max. & Mean & SD \\
\hline Volatility of tax rate & 0.001 & 0.633 & 0.022 & 0.048 \\
\hline Effective tax rate & 0.001 & 0.250 & 0.041 & 0.043 \\
\hline Firm size & 3.865 & 7.374 & 5.722 & 0.588 \\
\hline Market to book equity & -20222 & 29495 & 2581 & 3179 \\
\hline Financial leverage & 0.001 & 3.522 & 0.665 & 0.381 \\
\hline Optional Accrual Items & $0.001<$ & 5.615 & 0.470 & 0.518 \\
\hline Profitability & -38.85 & 2.71 & -0.052 & 2.703 \\
\hline Institutional ownership & 0 & 1 & 0.86 & 0.34 \\
\hline Cash flow risk & -0.706 & 5.412 & 0.384 & 0.470 \\
\hline NOLCF & $0.001<$ & 3.565 & 0.253 & 0.316 \\
\hline CHG-NOLCF & -3.35 & 3.055 & -0.005 & 0.281 \\
\hline Firm losses & 0 & 1 & 0.095 & 0.294 \\
\hline Equity logarithm & 3.62 & 8.30 & 5.47 & 0.67 \\
\hline
\end{tabular}

Looking at the details, it can be interpreted that almost one out of every ten of Iranian firms had negative pretax income. Furthermore, two-thirds of the total assets of a firm included debt; in fact, the companies that have used more debt to finance its assets are a leveraged company. In addition, the average of institutional ownership in Iran was approximately 86 percent. This implies that in the turbulent economic conditions of Iran market, the government has tried to take control of the whole market indirectly. Another interesting point is that on average, the rate of Optional Accrual Items is very high (\%47) because Iranian firms had many financial problems and had to engage in earnings management activities.

\subsection{The Results of the First Hypothesis}

As a result, after calculating effective tax rates, their average value is calculated to be 0.0692 . The effective tax rates of each year-firm are deducted from the average and then using a conditional formula in Excel software, the numbers whose differences are negative was assigned the value of 0 and the numbers whose difference is positive was assigned value of 1 . As previously stated in full, if the average number is close to zero indicating higher sustainability of low effective tax rates, and if it is close to one suggesting higher sustainability of higher effective tax rates. Hence, an average of these numbers was calculated, 
which was equal to 0.29 . This shows that the majority of numbers are zero so that the difference between the effective tax rate and the average is negative, and this shows that low effective tax rates are more consistent than high effective tax rates. As a result, the first hypothesis of the research is accepted. This means that low tax rates tend to be more persistent than high tax rates in Iran market.

\subsection{The Results of the Second Hypothesis}

In this study, we also have a tendency to investigate the relation between tax avoidance (low effective tax rate) and future tax rate volatility. Hence, the outcomes of the first research model are followed as:

Table 2: Results of the first model

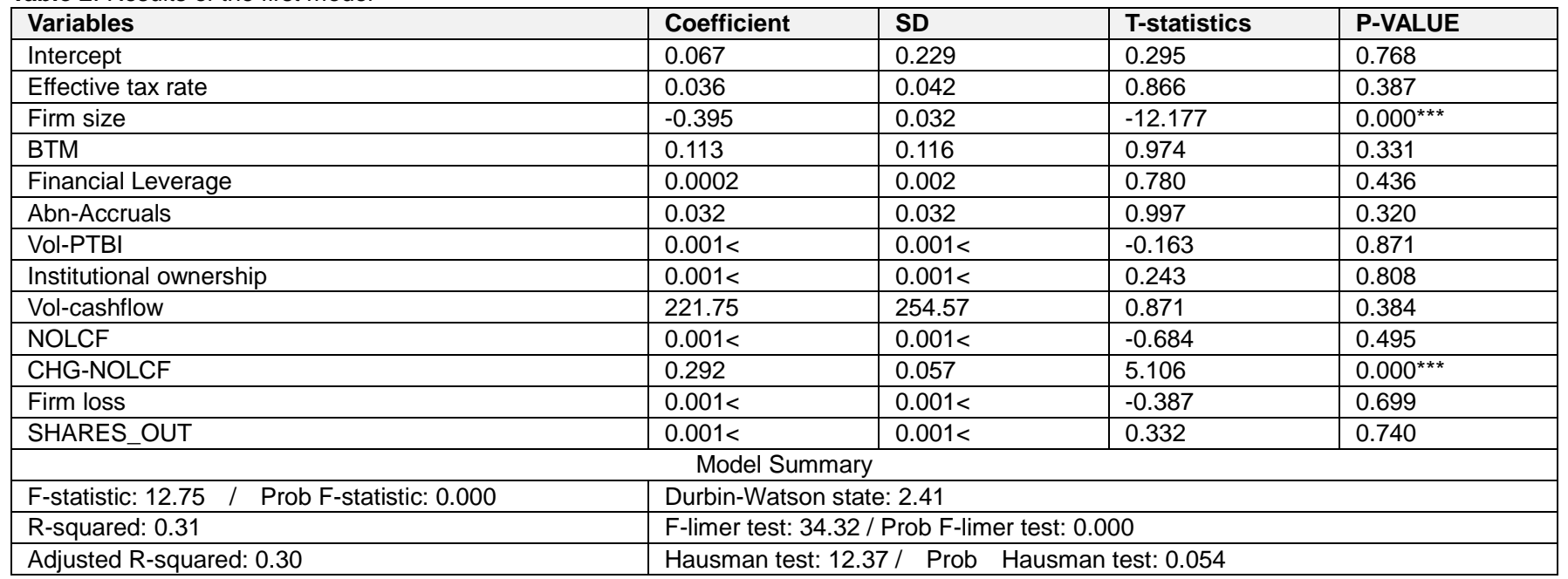

It is very important to evaluate to the significance of the research model before approval or rejection of the hypothesis. This can be done by calculating the F statistic and P-value of this statistic. Since P-value calculated for this statistic is less than 0.05 , the significance of the first model can be confirmed at five-percent error level. Based on econometric science, in the initial step, the F-Limer test is used for the sake of identifying whether the model is fitted to the Ordinary Least Squares (OLS) or panel data method (Salehi et al., 2018). In this test, H0 indicates using an OLS regression model is preferable, but $\mathrm{H} 1$ shows a panel data pattern must be used. It should be noted that since the amount of the p-value is less than five percent, HO is rejected and $\mathrm{H} 1$ is accepted. Thus, a panel data method must be employed. Afterward, the Hausman test is used to determine whether a panel data with fixed effects should be used or a panel data with random effect. According to this test, $\mathrm{H0}$ states that the panel data with random effects is suitable, whereas $\mathrm{H} 1$ indicates the panel data with fixed effects is better (Salehi et al., 2018). Because the amount of p-value is 0.054 and more than \%5, it can be said that $\mathrm{H} 0$ is accepted and the random effects model is superior to the fixed effects. In addition, one of the important assumptions in the regression model states that the regression residuals should have the lack of serial autocorrelation. Since the amount of Durbin-Watson state for all models is 2.41 (between $1.5 \& 2.5$ ). This provides strong evidence of the lack of serial autocorrelation in the residuals.

What stands out of the table above is that the second hypothesis failed to accept. In other words, since the amount of p-value for ETR variable is 0.387 and more than \%5, we find that there is no any significant relationship between tax avoidance and future tax rate volatility. Moreover, we found that the high level of future tax rate volatility is observed in smaller firms. The results also demonstrated that a change in the ratio of net operating profit is positively associated with future tax rate instability. However, the future tax rate volatility was not statistically influenced by other variables.

\subsection{The Results of the Third Hypothesis}

In the second model of this research aimed at investigating the association between tax avoidance and future stock price volatility. 
Mahdi SALEHI, Sharbanoo KHAZAEI, Hossein TARIGHI / Journal of Asian Finance, Economics and Business Vol 6 No 4 (2019) 45-52

Table 3: The results of the second model

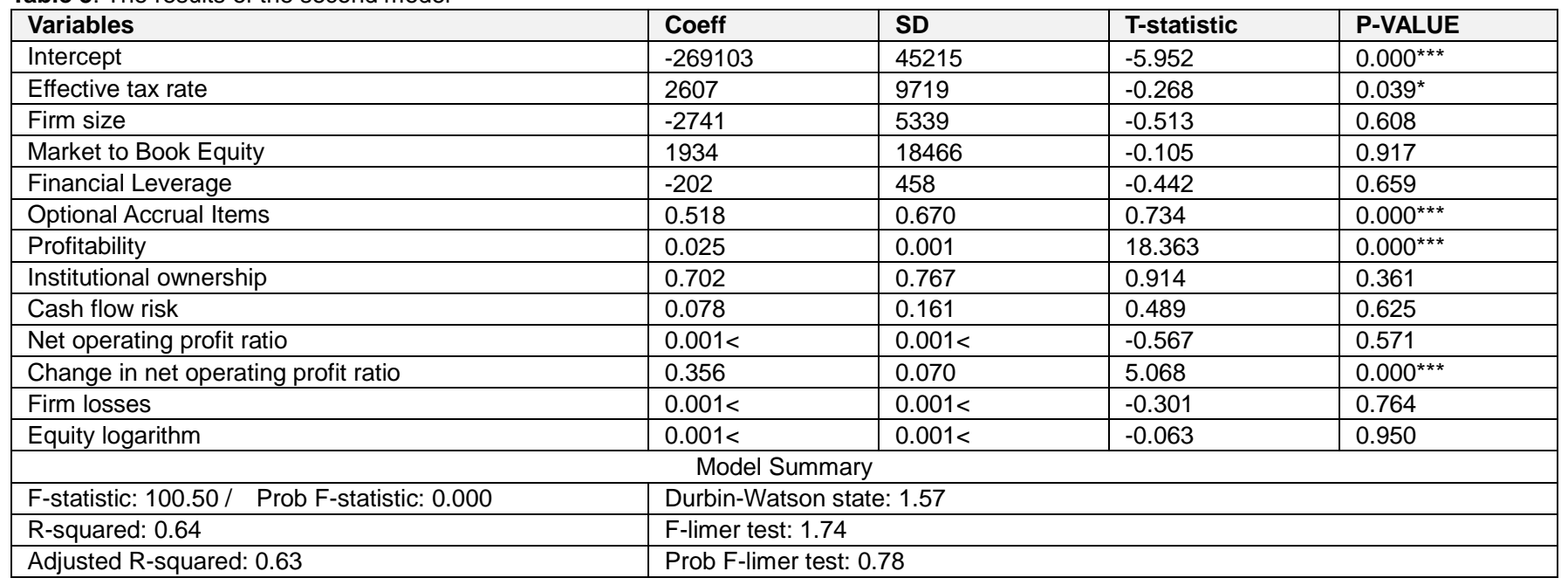

With respect to the table 3 , the most important point is that because the results of F-limer (Chow) test showed that the OLS regression, there is no need to carry out the Hausman test. We also can say that $64 \%$ of changes in the dependent variable are explained by independent variables. This implies that the high value of $\mathrm{R}$-squared shows our second model will fit better data. Our findings witnessed a positive connection between tax avoidance and future stock price volatility, which this shows the second hypothesis of this study is succeed to accept. The results showed that the firms with higher optional accrual items \& profitability have undergone a major change in their stock prices. Change in net operating profit also was one of the important factors in changing the corporate stock prices.

\section{Conclusion}

The first hypothesis of this study showed that a low effective tax rate (tax avoidance) is more consistent than the high effective tax rate. As a result, the first hypothesis of the research is accepted, and his result is consistent with results of Chen et al. (2010), Richardson et al. (2016), and Guenther et al. (2016). The results also displayed that there is no considerable connection between the effective tax rate (tax avoidance) and the future tax rate volatilities. Hence, the second hypothesis of the research has been rejected, and our findings are consistent with Frank et al. (2009), Richardson et al. (2016), and Guenther et al. (2016). In addition, we find strong evidence that there is a significant relationship between tax avoidance and the future stock price volatility. which this is similar to the studies of Chen et al. (2010), Foroghi et al. (2012), Guenther et al. (2016), and Moradi et al. (2016).

In general, since Iran country was faced with the severe economic sanction, mostly Iranian firms had financial stress. In such disastrous economic situations, corporate executives engaged in tax avoidance activities for a long time in order to decrease the corporate costs and show better their financial situation against the major shareholders. To do this, managers were likely to have a tendency to delay the disclosure of bad news about their firms. As a result, the accumulation of negative news by managers in this way creates a stock price bubble. Apparently, when a huge number of negative news reaches its peak, they immediately will enter the market and lead to a remarkable fluctuation in stock prices. In short, without any exaggeration, the results of this study will have many useful implications for investors and other users of financial statements. This research will make them of this fact that tax avoidance might be effective in increasing the stock price fluctuations in emerging markets, particularly those markets struggling with financial sanctions like Iran. Secondly, this paper will make users of financial statements aware of the effect of tax avoidance activities on overall firm risk, so that they can make a better valuation of financially poor companies.

Given that the majority of corporate executives by applying a low tax rate pursue their own goals, it is therefore suggested that investors, shareholders, and owners of the firms provide conditions that prevent management from providing false and manipulated information on cost (especially manipulation of tax income) and to provide reliable and accurate information to shareholders and owners. Also, according to the results of the research, it is suggested that the Iranian National Tax Administration provide maximum supervision on firms so that managers avoid tax evasion. Anyway, tax avoidance can have irreparable damages to the macroeconomic framework of each country; therefore, we highly recommend tax authorities for more specialized controls over tax avoidance actions.

\section{References}

Armstrong, S. C., Blouin, L. J., \& Larker, F. D. (2012). The 
incentives for tax planning. Journal of Accounting and Economics, 53(1), 391-411.

Badertscher, B., Katz, S., \& Rego, S. (2013). The separation of ownership and control and its impact on corporate tax avoidance. Journal of Accounting and Economics, 56, 228-250.

Balakrishnan, K., Blouin, J., \& Guay, W. (2018). Tax aggressiveness and corporate transparency. The Accounting Review, 94(1) 45-69. doi.org/10.2308/accr52130

Bushman, R. M., \& Smith, A. J. (2001). Financial accounting information and corporate governance. Journal of Accounting and Economics, 32(1-3), 237-333.

Chen, K. P., \& Chu, C. C. (2005). Internal control versus external manipulation: A model of corporate income tax evasion. RAND Journal of Economics, 36(1), 151-164.

Chen, S., Chen, X., Cheng, Q., \& Shevlin, T. (2010). Are family firms more tax aggressive than non-family firms? Journal of Financial Economics, 95(1), 41-61.

Chen, Y., Ge, R., Louis, H., \& Zolotoy, L. (2019). Stock liquidity and corporate tax avoidance, Review of Accounting Studies, 24(1), 309-340. https://doi.org/10.1007/s11142-018-9479-6

Crabtree, A., \& Maher, J. J. (2009). The influence of differences in taxable income and book income on the bond credit market. The Journal of the American Taxation Association, 31(1), 75-99.

Crocker, K. J., \& Slemrod, J. (2005). Corporate tax evasion with agency costs. Journal of Public Economics, 89(910), 1593-1610.

Dechow, P. M., Sloan, R. G., \& Sweeney, A. P. (1995). Detecting earnings management. Accounting Review, 70(2), 193-225.

Desai, M., \& Dharmapala, D. (2009). Corporate tax avoidance and firm value. Review of Economics and Statistics, 91(3), 537-546.

Dyreng, S. D., Hanlon, M., \& Maydew, E. L. (2018). When does tax avoidance result in tax uncertainty? The Accounting Review, 94(2) 179-203. doi.org/10.2308/accr-52198

Foroghi, D., Mirzaei, M., \& Rasaiian, A. (2012). The impact of tax avoidance on the future stock price crash risk of the listed companies in Tehran Stock Exchange. Journal of Tax Research, 13. Retrieved from http://taxjournal.ir/article-1-68-en.html

Frank, M. M., Lynch, L. J., \& Rego, S. O. (2009). Tax reporting aggressiveness and its relation to aggressive financial reporting. The Accounting Review, 84(2), 467496.

Graham, J. R., \& Tucker, A. L. (2006). Tax shelters and corporate debt policy. Journal of Financial Economics, 81(3), 563-594.

Guenther, D. A., Matsunaga, S. R., \& Williams, B. M. (2016). Is tax avoidance related to firm risk? The Accounting Review, 92(1), 115-136.
Hanlon, M., \& Heitzman, S. (2010). A review of tax research. Journal of Accounting and Economics, 50(2-3), 127-178.

Hasan, I., Hoi, C. K., Wu, Q., \& Zhang, H. (2014). Beauty is in the eye of the beholder: The effect of corporate tax avoidance on the cost of bank loans. Journal of Financial Economics, 113(1), 109-130.

Hutton, A. P., Marcus, A. J., \& Tehranian, H. (2009). Opaque financial reports, R2, and crash risk. Journal of Financial Economics, 94(1), 67-86.

Jensen, M., \& Meckling, W. (1976). Theory of the firm: Managerial behavior, agency costs and ownership structure. Journal of Financial Economics, 3, 305-360.

Kim, J. B., Li, Y., \& Zhang, L. (2011). Corporate tax avoidance and stock price crash risk: Firm-level analysis. Journal of Financial Economics, 100(3), 639-662.

Kothari, S. P., Shu, S., \& Wysocki, P. D. (2009). Do managers withhold bad news? Journal of Accounting Research, 47(1), 241-276.

Mashaykhi, B., \& Seyyedi, J. (2015). Corporate governance and tax avoidance. Journal of Accounting Knowledge, 6(20), 83-103. Retrieved from http://jak.uk.ac.ir/article_964_en.html

Moradi, M., Bagherpour Velashani, M., \& Rostami, A. (2016). The relationship between tax evasion and future stock price crash risk: Evidence from companies listed in the Tehran Stock Exchange (TSE). Journal Management System, 5(17), 127-146. Retrieved from http://jik.srbiau.ac.ir/article_8422_en.html

Noor, R. M., Fadzillah, N. S., \& Mastuki, N. A. (2010). Corporate tax planning: A study on corporate effective tax rates of Malaysian listed companies. International Journal of Trade, Economics and Finance, 1(2), 189-193.

Pasternak, M., \& Rico, C. (2008) Tax interpretation, planning, and avoidance: Some linguistic analysis. Akron Tax Journal, 23(2), 32-48.

Rego, S. O., \& Wilson, R. (2012). Equity risk incentives and corporate tax aggressiveness. Journal of Accounting Research, 50(3), 775-810.

Richardson, G., Taylor, G., \& Lanis, R. (2016). Women on the board of directors and corporate tax aggressiveness in Australia: An empirical analysis. Accounting Research Journal, 29(3), 313-331.

Salehi, M., Tarighi, H., \& Rezanezhad, M. (2017). The relationship between the board of directors' structure and company ownership with corporate social responsibility disclosure: Iranian angle. Humanomics, 33(4), 398-418.

Salehi, M., Tarighi, H., \& Safdari, S. (2018). The relation between corporate governance mechanisms, executive compensation and audit fees: Evidence from Iran. Management Research Review, 41(8) 939-967. doi.org/10.1108/MRR-12-2016-0277

Shevlin, T., Urcan, O., \& Vasvari, F. (2013). Corporate tax avoidance and public debt costs. Available at SSRN 2228601. 